FESIEE

Fundación Emilio Soldevilla de la Investigación y Desarnollo

\section{Management Letters / Cuadernos de Gestión}

journal homepage: http://www.ehu.eus/cuadernosdegestion/revista/es/

ISSN: 1131-6837 / e-ISSN: 1988-2157

\title{
An Empirical Analysis of the Factors Influencing Social Entrepreneurship: A Gendered Approach
}

\section{Un análisis empírico de los factores que influyen en el emprendimiento social: un enfoque de género}

\author{
Ambreen Khursheed ${ }^{*}$, Maham Fatima ${ }^{a}$, Dr. Faisal Mustafa ${ }^{b}$, Dr. Rab Nawaz Lodhic, Ayesha Akhtar ${ }^{d}$ \\ ${ }^{a}$ Research Associate, UCP Business School, University of Central Punjab, Pakistan -maham.fatima@ucp.edu.pk - https://orcid.org/0000-0002-8407-6162 \\ ${ }^{b}$ Professor, Dean UCP Business School, University of Central Punjab, Pakistan-faisal.mustafa@ucp.edu.pk - http://orcid.org/0000-0003-4689-5711 \\ c Associate Professor, UCP Business School, University of Central Punjab, Pakistan- rabnawaz.lodhi@ucp.edu.pk - https://orcid.org/0000-0003-2120-358X \\ ${ }^{d}$ Research Associate, UCP Business School, University of Central Punjab, Pakistan-ayeshaakhtar@ucp.edu.pk - http://orcid.org/0000-0001-8373-5958
}

* Corresponding author: Senior Lecturer, PhD Scholar, UCP Business School, University of Central Punjab, Pakistan -ambreen.khursheed@ucp.edu.pk - http://orcid.org/00000003-1497-5848

\section{A R T I C L E I N F O}

Received 10 June 2020,

Accepted 19 January 2021

Available online 25 February 2021

DOI: $10.5295 / \mathrm{cdg} .201320 \mathrm{ak}$

JEL CODE: L31, L26

\begin{abstract}
A B S T R A C T
Purpose: This study examines how entrepreneurial ecosystem factors (entrepreneurial finance, entrepreneurial education, physical and commercial infrastructure, culture, and R\&D transfer activities) shape social entrepreneurial activities (SEA) of men and women.

Design/methodology/approach: Panel data from 35 countries are examined through General Methods of Moments (GMM) with Arellano Bond tests for the period of ten years (2005-2014).

Findings: Our results indicate that women are more likely to get involved in creation of social ventures. Further, the selected six entrepreneurial factors modify SEA in a significantly different manner for both genders.

Originality/value: Based on this analysis, this study is the first to provide deeper insights for improving the assessment of social entrepreneurial activities in efficiency and innovation driven economies within the entrepreneurial ecosystem.
\end{abstract}

Keywords: Social entrepreneurship; Entrepreneurial Ecosystem; Culture, Social ventures; Gender; Arellano Bond test.

R E S U M E N

Finalidad: Este estudio examina el modo en que los factores del ecosistema empresarial (financiación empresarial, educación empresarial, infraestructura física y comercial, cultura y actividades de transferencia de I+D) dan forma a las actividades empresariales sociales (AES) de hombres y mujeres. Diseño/metodología/enfoque: Para un periodo de diez años (2005-2014) se examinan datos de panel de 35 países mediante los Métodos Generales de Momentos (GMM), empleando el test de Arellano Bond.

Hallazgos: Nuestros resultados indican que las mujeres son más propensas a involucrarse en la creación de empresas sociales. Además, los seis factores empresariales seleccionados modifican las AES de una manera significativamente diferente para ambos géneros.

Originalidad/valor: Sobre la base de este análisis, el presente estudio es el primero en ofrecer una visión más profunda para mejorar la evaluación de las actividades empresariales sociales en economías impulsadas por la eficiencia y la innovación dentro del ecosistema empresarial.

Palabras clave: Emprendimiento social; Ecosistema empresarial; Cultura; Social ventures; Género; Test de Arellano Bond. 


\section{INTRODUCTION}

The current literature on social entrepreneurship (SE) indicates that attaining sustainable social gains is one of the main objectives for social entrepreneurship, which comprises various elements, processes, and results (Lumpkin et al. 2013; Omorede 2014). The societies are more interested to figure out more cost-effective and innovative ways for addressing social issues, "social ventures" - mainly initiated by motivated people known as "social entrepreneurs" - have received growing attention (Bhushan 2020). These people combine a business mindset with social aims for addressing largely discontented needs in their societies (Ashrafi et al. 2020).

The growing consideration of SE's significance in the field of social and economic wellbeing is raising academicians' interests in social venture creation process and its impacts on society (Dwivedi and Weerawardena 2018). Recent literature reveals a huge amount of research has precisely considered debating what is involved and not involved in the concept of SE. Because defining SE is not an easy task, mainly due to the lack of consistency in the existing definitions of SE along with the divergent viewpoints focused to understand the phenomenon (Shaw and Carter 2007; Perrini, Vurro and Costanzo 2010; De Bruin and Ferrante 2011). Moreover, SE is complex in detail due to its complicated nature as it comprises of two essential concepts; first is entrepreneurship and second is social outreach (Rey-Martí et al. 2016). Consequently, Dacin et al. (2010) narrated 37 definitions of the social entrepreneurship concept. Austin, Stevenson and Wei-Skillern (2006) defined social entrepreneurship (SE) as an activity possessing innovative and value-creating features and can be found everywhere such as in business, non-profit organizations or the public sector. Similarly, social entrepreneurship is considered an activity that brings innovative solutions required for the resolving of societal issues and plays a significant role in assembling concepts, ideologies, resources, capabilities, and social setups necessary for consistent social revolutions (Alvord, Brown and Letts 2004).

In recent years, the concept of social entrepreneurship has gained the consideration of both practitioners and academics, as revealed by an emerging body of theoretical studies and empirical communities (Wakkee et al. 2019; Ashrafi et al. 2020). Accordingly, there are signs of inclining interest in the discipline of social entrepreneurship, but still, it is revolving in the emergent phase of its lifecycle (Cohen and Winn 2007) with an in-process development of institutional legitimacy (Hall et al. 2010). Apart from the recent social entrepreneurial work, the existence of some studies with an ability to test the scope and simplification of propositions have been seen (Ferreira et al. 2017; Doherty 2018). Nevertheless, majority of the studies does not completely assess the influence of entrepreneurial ecosystem factors on SE; thus, the factors promoting or hindering social enterprises remain undiscovered (Kedmenec and Strašek 2017; Capella-Peris et al. 2020) and SE intentions undertheorized (Sharir and Lerner 2006; Van Slyke and Newman 2006). Further, research contributions that highlight contextual differences among countries open new avenues for further research due to a lack of generalizability in the findings of studies. There- fore, this study fills the existing gap, as it determines how global entrepreneurial ecosystem factors (access to finance, education, culture and norms, physical infrastructure, commercial infrastructure and R\&D transfer) shape social entrepreneurial activities of men and women.

For getting deeper insights into the role of gender in the creation of social enterprises, it is crucial to understand the entrepreneurial ecosystem factors. These factors are dynamically involved in the complex interlinkage creation among social entrepreneurs who ultimately shape the growth of an entrepreneurial society. Additionally, the conceptual perspective and scope of social entrepreneurship have been positively evolved, however, a huge research gap exists with evident challenges for women as social entrepreneurs (Goyal and Parkash 2011). Therefore, accessing the perception of Levie and Autio (2008), we present a cultural and social experiment-based investigation of social entrepreneurship integrated with entrepreneurial framework coupled with time. We investigated a panel data of ten years (2005-2014) collected from global entrepreneurship monitor (GEM) for examining the influence of entrepreneurial ecosystem factors on social venturing rates in 35 countries for both genders. We examined the data through a rigorous statistical method "General Method of Moments" GMM and robustness checks (Arellano and Bond 1991). Precisely, this study examines how entrepreneurial ecosystem factors differently affect male and female involvement in social entrepreneurial activities.

This study provides three valuable contributions to the existing field of social entrepreneurship. First, this study makes a primary effort in examining social entrepreneurship; entrepreneurial education, research and development (R\&D) transfer, access to finance, physical infrastructure, commercial infrastructure and culture. Our outcome reveals that three out of six selected factors shape social entrepreneurial activities in a considerably different manner. Second, this study expands our understanding of male and female social entrepreneurial activities as we affirm that some factors influence male and female enterprises equally, some negatively and others have no significant impact. Third, by examining large scale data, this paper contributes to the present scarce empirical studies on social entrepreneurship and improves the generalizability of results on factors that influences social entrepreneurial activities in an entrepreneurial ecosystem (Urban and Kujinga 2017; Clark, Newbert and Quigley 2018; Hsu and Wang 2019; Capella-Peris et al. 2020).

The first section of this study provides the background of the social entrepreneurship then in the second section the literature is discussed. The third section presents the methodology and fourth section presents the results of the analyzed data. The fifth section shows the discussion and conclusion. The sixth section presents the implications with future directions.

\section{LITERATURE REVIEW}

\subsection{GEM and Social Entrepreneurial Activities}

The global entrepreneurship monitor (GEM) Social Entrepreneurship survey approach sees social entrepreneurs 
as those people who show positive response whether alone or with others to the involvement in commencing or owing to any kind of entrepreneurial activity with a clear purpose in social, societal and environmental perspective (Reynolds et al. 2005). To reach the likelihood of individuals engaging with social entrepreneurial activities, we completely consider identified nascent entrepreneurs for this aim. But these individual entrepreneurs are more likely to positively answer one question according to GEM methodology i.e. Do they have any type of involvement in any project, business start-up or entrepreneurial activity by showing some relative environmental, societal, social or cultural purpose? (Mair and Marti 2006; Zahra et al. 2009). The dependent variable is concerned with value 1 in case of a positive individual response, otherwise with 0 value.

Entrepreneurial ecosystems are a set of interdependent factors that are precisely coordinated for empowering productive entrepreneurship within a specific boundary (Feld 2012). The functional aspects of the entrepreneurial ecosystem show relative association with entrepreneurship and welfare outcomes (Feld 2012). Entrepreneurial ecosystems possess certain characteristics such as a foundation of large established business; entrepreneurial recycling- a process in which people reinvest their money, time and especially expertise for the initiation of new endeavors and informational setups that provide accessibility of information to everyone (Acs, Stam, Audretsch and O'Connor 2017). We remained focused on the GEM conceptual approach of Reynolds et al. (2005) and the entrepreneurial framework conditions (EFC) module of the GEM model. This module is effective in highlighting conditions that empower productive social entrepreneurship (Bhushan 2020). It measures incentive structures necessary for social entrepreneurship development. The global entrepreneurship model is a multi-level model, in this model EFCs are presented at national level. While entrepreneurial capacity, opportunity and activity are considered at the individual level and are totaled to the national level. Thus, the conceptualized model implies that social entrepreneurial activity at the national and individual levels is subject to various environmental parameters. The GEM model mainly considers structural conditions that regulate the effort allocation into social entrepreneurship at population level. A comprehensive social-economic phenomenon such as country-level social entrepreneurial activities involves individual capabilities as well as actions visualized by the system's incentives (Welter 2011; Sahasranamam and Nandakuma 2020). Consequently, the EFCs deals with country-level entrepreneurship to determine the percentage of entrepreneurial activities uniquely done by both genders. The reason behind this research is to favor the fact that the set-up of social structure and incentive procedures apply some discrimination in genders in the social venture creation process. Given existing literature, we formulated the following research question that how entrepreneurial ecosystem factors affect the social entrepreneurial activities of men and women? We have selected six entrepreneurial factors (entrepreneurial education, $\mathrm{R} \& \mathrm{D}$ transfer, access to finance, physical infrastructure, commercial infrastructure and culture) due to their importance in examining social entrepre- neurial activities (Desa 2012; Beckmann et al. 2014; Mustafa et al. 2018; Hakberstadt et al. 2019; Canestrino et al. 2020) Following sub-questions of the study are developed.

1. Does entrepreneurial education influence social entrepreneurial activities and is it more beneficial for men than women?

2. How R\&D activities influence social entrepreneurship at the national level and are such activities more favourable for establishing social entrepreneurial ventures by women than men?

3. What role does financial support play in enhancing social entrepreneurial activities and is it more easily available to men than women?

4. What is the role of physical infrastructure in boosting social entrepreneurship at the national level and is it more accessible to men than women?

5. What is the role of commercial infrastructure in boosting social entrepreneurship at the national level and is it equally supporting both men and women?

6. Do social and cultural norms influences social entrepreneurial activities and are these activities more favourable for men than women?

\subsection{Research hypotheses}

Entrepreneurial education is defined in the context of innovation and creativity applied to a wide range of areas such as business, societal or public sector (Ahmed et al. 2010). Past research highlighted that education promotes an increase in the supply of entrepreneurs by ensuring exceptional skills in individuals to go beyond the territories of routine businesses and initiates thinking more broadly on entrepreneurial activities (Deb and Bhatt 2020). It plays important role in exploring cognitive abilities to properly accomplish the process of recognition of opportunities along with a fine assessment and manipulation (DeTienni and Chandler 2004). Research indicates the existence of a positive relationship between entrepreneurial education and entrepreneurial activities (Delmar and Davidsson 2000). However, several studies found that women face more hurdles in their entrepreneurial careers due to a lack of access to education specifically focused on women-led business startups (Hashmi 2019). Hence, we propose that countries enriched with a diverse and prominent transparent educational system favoring entrepreneurship are more likely to evolve social entrepreneurial activities and this factor is more influential on men than women.

H1: Entrepreneurial education is directly associated with social entrepreneurial activities.

$H 1_{b}$ : Entrepreneurial education is more favorable for men than women.

Research and development (R\&D) transfer is the capacity of the national research and development process to direct new business projects and commercial opportunities along with the availability to SMEs (Amorós et al. 2019). By keeping in view this concept, the knowledge spillover theory of entrepreneurship states that seeking an optimistic interest in different companies' knowledge that still needs to be explored by markets and 
needs to be commercial facilitates to grow as an entrepreneur (Acs et al. 2008). Entrepreneurship exploits new knowledge due to the multifaceted portfolio of knowledge which shows a combination of a higher level of information along with uncertainty and asymmetry (Kong et al. 2019). Consequently, entrepreneurship is actively high in those countries in which quick and cheap transference of knowledge by incumbents to entrepreneurs is available in contrast to those countries where this transference is time-consuming and expensive. Markman et al. (2004) stated the positive relationship between entrepreneurship and incentive methodology in the case of university expertise transfer workplace personnel. While incentive methodology showed a negative relation to scientists' involvement in entrepreneurial activities. Therefore, we propose that at the national entrepreneurship stage, the impact of sharing knowledge influences both men and women but shows preference in its influence mainly on women. Thus, the following hypotheses are proposed.

$H 2_{a}: R \& D$ activities are positively associated with social entrepreneurship at the national level.

$\mathrm{H} 2_{b}$ : R\&D transfer is more favorable for women than men.

Blanchflower et al. (2003) defined entrepreneurial finance in terms of availability of financial funds i.e. debt and equity for small and moderate level businesses. Similarly, Shane (1996) documented that the exploitation of new opportunities is more usual where access to finance is easier. In this aspect, the consideration of gender is also very important as it involves both supply and demand-side debates for understanding the impact of financial support on SEA rates of men and women (Ahl 2004). On one hand, the demand debate reveals risk of declined access of women entrepreneurs to outdoor investments (Mittal and Vyas 2011). Whereas, Marlow and Patton (2005) discuss that females require more investment and credit when stepping forward to initiate any business activity.

On the other hand, supply-side debate considers the risk of discrimination of the female gender by financial institutions (Alibhai et al. 2019). Research witnessed that the female gender faces more difficulties in getting loans from official financial institutions, believed by business owners as well (Pergelova et al. 2019). Thus, the female gender is more exposed to finance and credit hurdles in initiating business setups rather than men. Because of the above discussion, we propose the following hypotheses.

H3: Social entrepreneurship exhibits direct association with financial support.

$\mathrm{H} 3_{b}$ : Financial support is more easily available for men than women.

Physical infrastructure is the convenience in accessing different physical resources including transportation, communication, land, building and utilities at a cost that favors SMEs (Amorós and Bosma 2014). Specific infrastructure programs matching with relative industry can be supportive for new endeavors and also speed up new projects in the relevant industry (Audretsch et al. 2015). This factor has such a vital role that it can act as a huge barrier in launching a new business (Ghani et al. 2014). A few studies that determined the role of physical infrastructure in enhancing social entrepreneurship have been subject to noticeable subsequent limitations. Thus, we come up with the belief that physical infrastructure influences SEA rates and it exhibits a stronger impact on men as compared to women.

H4: At the national level, social entrepreneurship is positively associated with physical infrastructure.

$\mathrm{H}_{b}$ : Physical infrastructure is more accessible to men as compared to women.

Commercial infrastructure is associated with business and litigation activities that are necessary for all businesses. It shows concern for certain activities in the background linked with firm creation including subcontractors, customers, suppliers, advertising, marketing, financial attractiveness, consultants and legal services (Harrington et al. 2019). An alert focus on the availability of commercial and legal infrastructure facilitates business in having an exceptional competitive advantage. Whereas, any negligence in these services leads to declined social entrepreneurial effort (Kruse et al. 2019). Therefore, we propose to investigate this key relationship by examining the influence of commercial infrastructure on both genders.

H5: Social entrepreneurship is positively associated with commercial infrastructure.

$\mathrm{H}_{b}$ : Commercial infrastructure significantly influences the social entrepreneurial actives of men and women.

Amorós and Bosma (2014) states that the scope of social and cultural norms motivates actions required for new endeavors to positively contribute to the maximization of personal wealth. In the debate of social and cultural norms, the first thing to be considered is the distinction among parameters of national culture (Hofstede 1980; Schwartz 1994; Inglehart 1997; House 1998) compared with particular beliefs or attitudes regarding social entrepreneurship (Levie and Autio 2008). Considerable change has been seen in national as well as social values, beliefs and attitudes regarding entrepreneurship (Etzioni 1987; Lounsbury et al. 2019) unlikely universal values (Inglehart 1997). Constructive publicity, media perspective and societal admiration for entrepreneurship (viewed in the parameters of attitude towards those who have earned personal wealth under the scope of entrepreneurship) show influence on desirability and engagement of social entrepreneurship at the individual level (Doherty 2018). Research witnessed less engagement of women toward social entrepreneurial activities in those countries which are enriched in aggressive institutional setup (Digan et al. 2019). Also, female entrepreneurial movements are comparatively at higher risk to be impacted by cultural environment in contrast to men (Brush et al. 2019). The more is the probability of women's entrepreneurial activities to be susceptible by cultural values and beliefs, the more likely women are influenced by the norms regarding entrepreneurship. Thus, we propose the following hypotheses.

H6: Social and cultural norms are directly associated with social entrepreneurial activities.

$\mathrm{H6}_{b}$ : Social and cultural norms are more favorable for men than women.

We categorized control variables in the light of economic and social outlook. We selected the world bank (WB) database for the determination of country's GDP per capita for every corre- 
sponding year and calculated it as recent US dollars (Van Stel et al. 2007; Acs et al. 2008). The size of any country is a crucial factor as it reveals the supply of individuals in the active labor force sector, ultimately affecting social entrepreneurial ventures. Hence, we screened the size of population by attaining it from the WB database and mentioned population in our research. We used yearly-based dummies in the applied models of research patterns as instruments. The conceptual model of the study is presented in Figure 1.

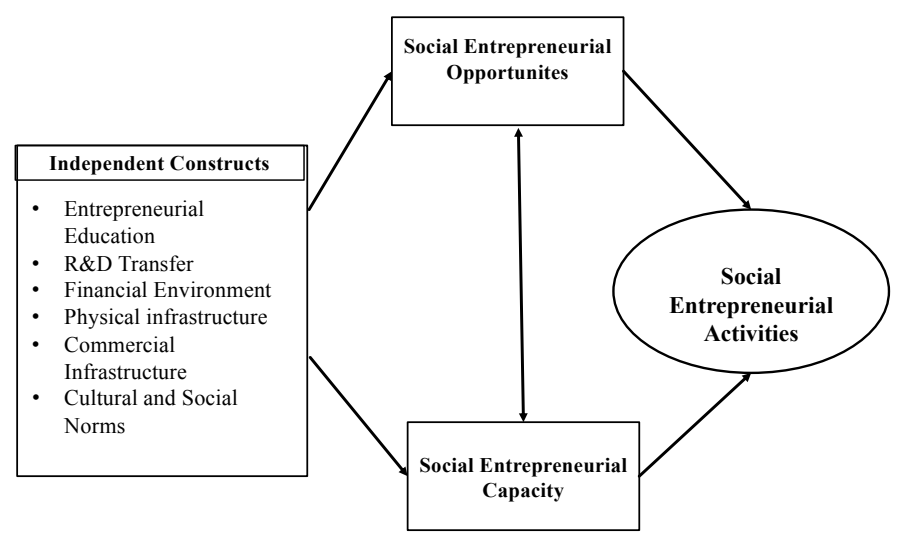

Figure 1

GEM Conceptual Model of the Study

Source: Own elaboration.

The definition of social entrepreneurship revolves around a variety of concepts. Each concept depicts a different meaning of the same unified term. This variation comes as the first significant barrier in the evolutional study of social entrepreneurship by scholars. The diversification in the perspective of defining social entrepreneurship comes from relating its meaning in the context of various disciplines such as economics, accounting, political sciences and entrepreneurship (Alter, 2007; Short et al. 2009). Despite the varied scope of defining social entrepreneurship, some other dominating factors give it a unique recognition from conventional entrepreneurship and usual charities. In the light of previous literature, three factors are listed as impacting ones: the emphasis on innovation, the role of earnings and the superiority of social mission (Dawson and Daniel 2010; Lehner and Kansikas 2012). The consideration of social innovation makes social mission achievable as revealed by the past studies in the aspect of social entrepreneurship (Shaw and Carter 2007; Perrini Vurro and Costanzo 2010; De Bruin and Ferrante 2011). The literature further adds that social entrepreneurship and social innovation are interlinked as both follow opportunity appreciation and social mission (Korsgaard 2011). Moreover, Ruvio and Shoham (2011) explained that for attaining success in social entrepreneurship, a requirement of launching innovative products and services to the market must be assured.

For understanding the influence of entrepreneurial factors on SEA rates we have used two theories. As our society is dealing with several economic and social challenges, while government efforts are unsatisfactory in managing such challenges. Therefore, this failure leads to the establishment of social entrepreneurial ventures that focuses to resolve issues by implementing innova- tive tools (Santos 2012). Prior studies claimed that all social enterprises have social underpinnings and their long-term success is dependent on their ability to achieve certain human goals that meet the potential, creativity and dignity of a freeman (Friedman 1970; Davis 1973; Dees and Elias 1998; Thompson 2002). Santos (2012) introduced a social entrepreneurship theory that explicates the role of social entrepreneurs in the economic system. This theory explains that the central goal of social entrepreneurial ventures is value creation (producing a significant impact for society) or value capture (generating maximum value creation along with profit generation) and the failure of governmental efforts in resolving social issues leads to increase social entrepreneurial activities (SEA). Therefore, we have used this theoretical concept, as it is quite relevant for determining that whether prevalence of SEA rates of men and women are influenced by entrepreneurial ecosystem factors or these rates are independent of such factors.

However, for getting a deeper understanding of the impact of $\mathrm{R} \& \mathrm{D}$ transfer activities on SEA rates, we have used the 'knowledge spillover theory of entrepreneurship' introduced by Acs (2006). This theory presents the extension and merger of Schumpeterian and Romanian economic growth models (Acs 2009; Acs et al. 2013). This theory claims that knowledge by itself is essential but it is not enough condition for enhancing economic growth. As all inventions may not automatically transform into innovations and similarly all types of research knowledge are not capable to provide commercialized useful knowledge. Therefore, to contribute to the development of an economy a research knowledge needs to be transformed into economically beneficial knowledge and discoveries need to be transformed into innovations. In the accordance with this theory:

"Entrepreneurship plays a vital role in boosting the economic growth by serving as a channel although it is not the only channel by which the knowledge produced by incumbent organization spills over to the agents who endogenously produce a new organization."

Thus, in line with knowledge spillover theory, this study examines that countries in which knowledge transfer generated through R\&D activities is relatively fast and inexpensive should create more social startups or enhance social entrepreneurial activities than those in which these activities are expensive and slow. Despite existing research on individual and contextual antecedents of social entrepreneurship, little research has investigated the impact of entrepreneurial ecosystem factors on SEA. For getting deeper insights past researchers have mostly applied theory of planned behavior and effectuation theory (Prieto et al. 2012; Servantie and Rispal 2018; Chandra and Paras 2020) but in this study, we have incorporated two crucial theories to better understand the potential impact of entrepreneurial ecosystem factors on SEA.

\section{METHODOLOGY}

The structure of our final sample covers 35 countries selected based on data availability of SEA prevalence rates from 2005 to 2014. Although the formation of our data seems as an unstable dynamical longitudinal panel, we used the General Method of Moments (GMM) estimator to deal with probable endogeneity and unanalyzed heterogeneity (Arellano 2003). To test the 
research objectives of the study, first, we checked the descriptive statistics, then the diagnostic checks of GMM are applied, which includes Hansen and Wald chi-square test. After diagnostic checks, the GMM test with the Arellano Bond test is applied for checking first-order (AR1) and second-order (AR2) serial correlation. This facilitated our study to observe auto aggressive distributed lagged models from unstable panels with various elements measured on cross-sectional period kept for comparatively limited periods.

Our study unlocks three data sources in the model analysis of secondary data. Our sample comprises of country-level sources: Adult Population Survey (APS), National Expert Survey (NES) and Global Entrepreneurship Monitor (GEM) (Reynolds et al. 2005). The percentage representation of social entrepreneurship involvement at the initial level is taken as a dependent variable, which comes from GEM 2015 data (Bosma et al. 2016). GEM has earned a reputation for providing the largest dataset for social entrepreneurial activities done worldwide by interacting with 103,593 persons from 35 countries. GEM declares the meaning of social entrepreneurship in terms of individual involvement in entrepreneurial activity by concerning any kind of social, legal, commercial and environmental aspect.

\section{RESULTS}

The bivariate and descriptive statistics are presented in Table 1. Variance inflation factor (VIF) is used for calculating separate regression models. The mean VIF for the whole data of social entrepreneurial activity (SEA) is 3.09 for male SEA, and 3.14 for female SEA, as VIF is below 10 so it is considered suitable (Craney et al. 2002). The results presented by General Methods of Moments (GMM) are depicted in Table 3. According to our results entrepreneurial education showed a positive effect on male SEA rates $(\beta=2.109 ; p=0.012)$ and female SEA rates $(\beta=5.118$; $p=0.004)$. This shows that entrepreneurial education positively influences social entrepreneurial activities. Thus, proving $\mathrm{H} 1_{\mathrm{a}}$, however, $\mathrm{H}_{\mathrm{b}}$ is not supported by our results as the impact of entrepreneurial education is found higher for women as compared to men.

In case of $\mathrm{R} \& \mathrm{D}$ transfer the male SEA rates $(\beta=-2.402$; $\mathrm{p}=0.009)$ and female SEA rates $(\beta=-4.134, \mathrm{p}=0.003)$. This shows that the countries having research and development activities will have lesser social entrepreneurial activities. Hence, $\mathrm{H} 2{ }_{\mathrm{a}}$ is not supported by results, but $\mathrm{H} 2{ }_{\mathrm{b}}$ is supported as the result reveals the impact of $\mathrm{R} \& \mathrm{D}$ transfer is stronger for women compared to men.
Overall access to finance positively influences male SEA rates $(\beta=3.069 ; \mathrm{p}=0.018)$ and female SEA rates $(\beta=2.492 ; \mathrm{p}=0.039)$. Thus, our results support $\mathrm{H} 3$ and $\mathrm{H} 3$, Thus, confirming the past studies that the availability of entrepreneurial finance for conducting social entrepreneurial activities plays a significant role, particularly for men.

Physical infrastructure and services found to positively and significantly influence female SEA rates $(\beta=1.198 ; \mathrm{p}=0.008)$ and male SEA rates $(\beta=3.017, \mathrm{p}=0.001)$ with stronger impact on male SEA rates. The results reveal that $\mathrm{H} 4 \mathrm{a}$ and $\mathrm{H} 44_{\mathrm{b}}$ are supported. Further, we found that commercial infrastructure accessibility shares a significant and positive relationship with SEA rates for only females $(\beta=2.424, p=0.007)$. Our results partially supported $\mathrm{H} 5_{\mathrm{a}}$ and $\mathrm{H} 5_{\mathrm{b}}$ as only female SEA rates are found to be significant and positively related to commercial infrastructure. Cultural and social norms also found to significantly and positively influence social entrepreneurial activities, as the male SEA rates is $(\beta=3.514, p=0.004)$ and female SEA rates $(\beta=2.405 ; \mathrm{p}=0.003)$. Further, cultural impact is found to be more favorable for men. Thus, the results support $\mathrm{H} 6_{\mathrm{a}}$ and $\mathrm{H} 6_{\mathrm{b}}$.

\subsection{Robustness Checks}

For robustness checks, we classified our sampled 35 countries by their competitiveness across two phases of economic advancement; Efficiency driven economies (having scale intensity) and Innovation-driven economies (preferring the latest production methods for introducing innovative products and services). We have used these two classifications of countries for determining exclusive differences in ecosystem effects. In the perspective of innovation-driven economies, education shares a significant and positive effect on the social entrepreneurial activities of men and women. The male SEA rates are $(\beta=2.752 ; \mathrm{p}=0.013)$ and female SEA rates are $(\beta=2.113 ; \mathrm{p}=0.004)$. Likewise, access to finance also shares a positive and significant effects on SEA rates, for male SEA rates $(\beta=3.101 ; p=0.012)$ for female SEA rates $(\beta=2.341 ; p=0.011)$, while the commercial and legal infrastructure shares a significant and positive effect on both male and female SEA rates, for male $(\beta=0.314 ; p=0.003)$ for female $(\beta=0.252 ; p=0.041)$. While physical infrastructure reveals an insignificant relationship with SEA in innovation-driven economies.

In case of efficiency driven economies access to finance positively effects males SEA rates $(\beta=3.882 ; \mathrm{p}=0.024)$ and female SEA $(\beta=4.554 ; \mathrm{p}=0.006)$. Similarly, physical infrastructure positively influences both male SEA rates $(\beta=2.112 ; \mathrm{p}=0.003)$ and female SEA rates $(\beta=0.314 ; \mathrm{p}=0.009)$. 
Table 1

Descriptive and bivariate statistics

\begin{tabular}{|c|c|c|c|c|c|c|c|c|c|c|c|c|}
\hline Variable & Mean & S.D. & 1 & 2 & 3 & 4 & 5 & 6 & 7 & 8 & 9 & 10 \\
\hline Male SEA & 11.24 & 6.45 & 1 & & & & & & & & & \\
\hline Female SEA & 7.51 & 6.81 & $0.875^{\star *}$ & 1 & & & & & & & & \\
\hline $\begin{array}{l}\text { GDP per capita } \\
\text { PPP }\end{array}$ & $24,073.39$ & $22,626.52$ & $-0.397^{\star *}$ & $-0.495^{\star *}$ & 1 & & & & & & & \\
\hline \% GDP growth & 3.86 & 4.79 & $0.008^{*}$ & $0.243^{* *}$ & $-0.1 .65^{\star *}$ & 1 & & & & & & \\
\hline Population & $71,357,356.71$ & $399,675,056.88$ & 0.077 & 0.061 & -0.041 & $0.181^{\star *}$ & 1 & & & & & \\
\hline $\begin{array}{l}\text { Access to } \\
\text { finance }\end{array}$ & 3.41 & 0.32 & $-0.413^{\star \star}$ & $-0.613^{\star *}$ & $0.437^{\star *}$ & 0.079 & $-0.076^{\star}$ & 1 & & & & \\
\hline $\begin{array}{l}\text { Entrepreneurial } \\
\text { education }\end{array}$ & 3.98 & 0.21 & $-0.123^{\star \star}$ & $-0.129^{\star *}$ & $0.367^{\star *}$ & $0.198^{\star *}$ & 0.011 & $0.121^{*}$ & 1 & & & \\
\hline R\&D transfer & 3.98 & 0.41 & $-0.398^{\star *}$ & $-0.389^{* *}$ & $0.701^{\star *}$ & -0.041 & -0.059 & 0.071 & -0.051 & 1 & & \\
\hline $\begin{array}{l}\text { Commercial } \\
\text { and legal } \\
\text { infrastructure } \\
\text { access }\end{array}$ & 4.01 & 0.09 & $-0.411^{\star *}$ & $-0.431^{\star \star}$ & $0.561^{\star *}$ & -0.039 & -0.069 & 0.071 & -0.049 & $-0.142^{\star *}$ & 1 & \\
\hline $\begin{array}{l}\text { Physical } \\
\text { infrastructure } \\
\text { and services }\end{array}$ & 3.82 & 0.52 & $-0.301^{\star *}$ & $-0.209^{\star *}$ & $0.543^{\star *}$ & $-0.098^{\star}$ & 0.045 & $0.151^{\star *}$ & 0.008 & $-0.310^{\star *}$ & $-0.192^{\star *}$ & 1 \\
\hline $\begin{array}{l}\text { Cultural, } \\
\text { social norms } \\
\text { supportive }\end{array}$ & 3.01 & 1.23 & $0.098^{\star *}$ & $0.172^{\star *}$ & $0.187^{\star \star}$ & 0.165 & $0.257^{\star *}$ & $0.211^{\star *}$ & $0.255^{\star *}$ & $-0.303^{\star *}$ & $-0.321^{\star *}$ & $-0.328^{\star \star}$ \\
\hline
\end{tabular}

* significant at $\mathrm{p} \leq 0.05$

** significant at $\mathrm{p} \leq 0.01$

Source: Own elaboration.

Table 2

Regression models entrepreneurship rates of men and women

\begin{tabular}{|c|c|c|c|c|c|c|c|c|c|c|c|c|}
\hline & \multicolumn{3}{|c|}{ Male SEA rate (Control) } & \multicolumn{3}{|c|}{ Male SEA rate (Actual Effects) } & \multicolumn{3}{|c|}{ Female SEA rate (Control) } & \multicolumn{3}{|c|}{ Female SEA rate (Actual Effects) } \\
\hline & Beta value & $\begin{array}{l}\text { Standard } \\
\text { error }\end{array}$ & $\begin{array}{l}\text { Significance } \\
\text { value }\end{array}$ & $\begin{array}{l}\text { Beta } \\
\text { value }\end{array}$ & $\begin{array}{l}\text { Standard } \\
\text { error }\end{array}$ & $\begin{array}{l}\text { Significance } \\
\text { value }\end{array}$ & Beta value & $\begin{array}{l}\text { Standard } \\
\text { error }\end{array}$ & $\begin{array}{l}\text { Significance } \\
\text { value }\end{array}$ & Beta value & $\begin{array}{l}\text { Standard } \\
\text { error }\end{array}$ & $\begin{array}{l}\text { Significance } \\
\text { value }\end{array}$ \\
\hline $\begin{array}{l}\text { Entrepreneurship rate } \\
1 \text {-year lag }\end{array}$ & 0.697 & 0.089 & 0 & 0.382 & 0.561 & 0 & 0.697 & 0.14 & 0 & 0.732 & 0.213 & 0 \\
\hline Population & $0.01 \mathrm{E}+00$ & $0.01 \mathrm{E}+00$ & 0.592 & 0.000 & 0.000 & 0.019 & $0.01 \mathrm{E}+00$ & $0.00 \mathrm{E}+00$ & 0.513 & $0.01 \mathrm{E}+00$ & $0.01 \mathrm{E}+00$ & 0.011 \\
\hline GDP & $0.00 \mathrm{E}+00$ & $0.00 \mathrm{E}+00$ & 0.231 & 0.000 & 0.000 & 0.613 & $0.01 \mathrm{E}+00$ & $0.01 \mathrm{E}+00$ & 0.087 & $0.01 \mathrm{E}+00$ & $0.01 \mathrm{E}+00$ & 0.199 \\
\hline GDP growth & -0.031 & 0.069 & 0.811 & -0.015 & 0.062 & 0.793 & -0.056 & 0.063 & 0.379 & -0.042 & 0.049 & 0.451 \\
\hline Access to finance & & & & 3.069 & 1.549 & 0.018 & & & & 2.492 & 1.721 & 0.039 \\
\hline $\begin{array}{l}\text { Entrepreneurial } \\
\text { education }\end{array}$ & & & & 2.109 & 1.872 & 0.012 & & & & 5.118 & 1.641 & 0.004 \\
\hline $\mathrm{R} \& \mathrm{D}$ transfer & & & & -2.402 & 1.532 & 0.009 & & & & -4.134 & 1.912 & 0.003 \\
\hline $\begin{array}{l}\text { Commercial } \\
\text { infrastructure access }\end{array}$ & & & & -1.391 & 1.783 & 0.452 & & & & 2.424 & 1.367 & 0.007 \\
\hline Physical infrastructure & & & & 3.017 & 1.691 & 0.001 & & & & 1.198 & 1.231 & 0.008 \\
\hline $\begin{array}{l}\text { Cultural and social } \\
\text { norms }\end{array}$ & & & & 3.514 & 1.523 & 0.004 & & & & 2.405 & 1.421 & 0.003 \\
\hline 2005 & 3.623 & 1.642 & 0.679 & -3.125 & 2.541 & 0.254 & 1.093 & 0.042 & 0.652 & 1.254 & 1.651 & 0.321 \\
\hline 2006 & -1.945 & 1.498 & 0.216 & 2.541 & 0.253 & 2.1254 & 0.169 & 0.721 & 0.721 & 1.586 & 1.321 & 0.136 \\
\hline 2007 & -2.106 & 1.523 & 0.154 & 3.561 & 3.214 & 2.367 & -0.459 & 1.052 & 0.649 & 4.258 & 1.481 & 0.431 \\
\hline 2008 & 2.194 & 1.983 & 0.875 & -4.258 & 5.487 & 1.354 & 0.956 & 0.632 & 0.681 & -3.214 & 1.602 & 0.821 \\
\hline 2009 & 2.156 & 1.109 & 0.056 & 1.256 & 1.256 & 1.658 & -0.842 & 0.921 & 0.061 & 3.658 & 0.521 & 0.261 \\
\hline 2010 & 2.984 & 1.015 & 0.135 & -3.886 & 2.365 & 1.698 & 0.732 & 0.591 & 0.187 & 3.457 & 0.521 & 0.682 \\
\hline 2011 & 0.432 & 0.965 & 0.166 & -3.956 & 3.587 & 1.546 & 1.183 & 0.631 & 0.019 & -2.235 & 0.639 & 0.241 \\
\hline 2012 & -1.145 & 0.832 & 0.194 & 2.147 & 3.574 & 1.358 & 1.001 & 0.645 & 0.563 & 2.147 & 0.641 & 0.321 \\
\hline 2013 & 0.462 & 1.193 & 0.421 & 0.421 & 0.541 & 0.072 & 0.521 & 0.318 & 0.369 & 1.932 & 1.621 & 0.213 \\
\hline 2014 & 0.531 & 0.111 & 0.701 & -0.431 & 0.921 & 0.675 & 0.832 & 0.731 & 0.265 & 0.421 & 0.532 & 0.758 \\
\hline Intercept & -9.359 & 8.932 & 0.732 & -0.417 & 9.547 & 0.672 & -0.721 & 2.746 & 0.831 & 3.451 & 5.671 & 0.537 \\
\hline Countries & 35 & & & 31 & & & 35 & & & 31 & & \\
\hline
\end{tabular}




\begin{tabular}{|c|c|c|c|c|c|c|c|c|c|c|c|c|}
\hline & \multicolumn{3}{|c|}{ Male SEA rate (Control) } & \multicolumn{3}{|c|}{ Male SEA rate (Actual Effects) } & \multicolumn{3}{|c|}{ Female SEA rate (Control) } & \multicolumn{3}{|c|}{ Female SEA rate (Actual Effects) } \\
\hline & Beta value & $\begin{array}{l}\text { Standard } \\
\text { error }\end{array}$ & $\begin{array}{l}\text { Significance } \\
\text { value }\end{array}$ & $\begin{array}{l}\text { Beta } \\
\text { value }\end{array}$ & $\begin{array}{c}\text { Standard } \\
\text { error }\end{array}$ & $\begin{array}{l}\text { Significance } \\
\text { value }\end{array}$ & Beta value & $\begin{array}{c}\text { Standard } \\
\text { error }\end{array}$ & $\begin{array}{c}\text { Significance } \\
\text { value }\end{array}$ & Beta value & $\begin{array}{l}\text { Standard } \\
\text { error }\end{array}$ & $\begin{array}{l}\text { Significance } \\
\text { value }\end{array}$ \\
\hline $\mathrm{N}$ & 382 & & & 304 & & & 382 & & & 304 & & \\
\hline Hansen & 32.710 & & 0.19 & 68.92 & & 0.11 & 43.64 & & 0.085 & 42.14 & & 0.191 \\
\hline Wald $\mathrm{X}^{2 c}$ & 6.235 & 0.51 & 0.004 & 5.871 & 1.61 & 0.001 & 5.786 & 0.014 & 0.003 & 5.772 & 0.119 & 0.000 \\
\hline $\operatorname{AR}(1)$ & 2.890 & & 0.003 & 3.13 & & 0.005 & 2.89 & & 0.001 & 3.24 & & 0.004 \\
\hline $\operatorname{AR}(2)$ & 2.230 & & 0.345 & 1.67 & & 0.538 & 1.18 & & 0.419 & 1.19 & & 0.287 \\
\hline $\mathrm{R}^{2}$ & 0.649 & & & 0.811 & & & 0.745 & & & 0.779 & & \\
\hline
\end{tabular}

Source: Own elaboration.

Table 3

Sub-set regression models of innovation-driven economies

\begin{tabular}{|c|c|c|c|c|c|c|c|c|c|c|c|c|}
\hline & \multicolumn{3}{|c|}{ Male SEA rate (Control) } & \multicolumn{3}{|c|}{ Male SEA rate (Actual Effects) } & \multicolumn{3}{|c|}{ Female SEA rate (Control) } & \multicolumn{3}{|c|}{ Female SEA rate (Actual Effects) } \\
\hline & Beta value & $\begin{array}{c}\text { Standard } \\
\text { error }\end{array}$ & $\begin{array}{l}\text { Significance } \\
\text { value }\end{array}$ & Beta value & $\begin{array}{l}\text { Standard } \\
\text { error }\end{array}$ & $\begin{array}{l}\text { Significance } \\
\text { value }\end{array}$ & Beta value & $\begin{array}{l}\text { Standard } \\
\text { error }\end{array}$ & $\begin{array}{l}\text { Significance } \\
\text { value }\end{array}$ & Beta value & $\begin{array}{l}\text { Standard } \\
\text { error }\end{array}$ & $\begin{array}{l}\text { Significance } \\
\text { value }\end{array}$ \\
\hline $\begin{array}{l}\text { Entrepreneurship } \\
\text { rate 1-year lag }\end{array}$ & 0.841 & 0.042 & 0.002 & 1.735 & 0.426 & 0.101 & 0.718 & 0.027 & 0.012 & 2.067 & 1.16 & 0.003 \\
\hline Population & -1.2167 & 1.4612 & 0.405 & 3.0931 & 1.8098 & 0.297 & 1.5892 & 1.3561 & 0.314 & -1.7641 & 6.9632 & 0.003 \\
\hline GDP & 0.001 & 0.001 & 0.014 & 0.011 & 0.010 & 0.581 & 0.009 & 0.001 & 0.051 & 0.001 & 0.001 & 0.254 \\
\hline GDP growth & 0.010 & 0.031 & 0.716 & 0.114 & 0.140 & 0.645 & 0.012 & 0.021 & 0.278 & -0.076 & 0.338 & 0.541 \\
\hline Access to finance & & & & 3.101 & 3.014 & 0.012 & & & & 2.341 & 0.545 & 0.011 \\
\hline $\begin{array}{l}\text { Entrepreneurial } \\
\text { education }\end{array}$ & & & & 2.752 & 4.050 & 0.013 & & & & 2.113 & 0.655 & 0.004 \\
\hline R\&D transfer & & & & -1.771 & 4.476 & 0.624 & & & & 1.217 & 0.842 & 0.412 \\
\hline $\begin{array}{l}\text { Commercial } \\
\text { infrastructure access }\end{array}$ & & & & 0.314 & 6.013 & 0.113 & & & & 0.252 & 1.025 & 0.441 \\
\hline $\begin{array}{l}\text { Physical } \\
\text { infrastructure }\end{array}$ & & & & 2.762 & 2.166 & 0.912 & & & & -0.165 & 0.625 & 0.541 \\
\hline Cultural norms & & & & -2.142 & 3.551 & 0.831 & & & & 0.103 & 0.446 & 0.281 \\
\hline 2005 & 2.541 & 1.054 & 0.003 & 2.314 & 1.054 & 0.115 & 0.542 & 0.326 & 0.242 & 1.825 & 1.171 & 0.321 \\
\hline 2006 & 2.562 & 1.678 & 0.070 & 2.562 & 1.420 & 0.060 & 0.221 & 0.321 & 0.457 & 1.761 & 1.132 & 0.121 \\
\hline 2007 & 0.508 & 0.951 & 0.732 & 1.010 & 2.330 & 0.510 & 0.231 & 0.177 & 0.765 & 1.082 & 1.321 & 0.132 \\
\hline 2008 & 1.496 & 0.624 & 0.030 & 1.128 & 2.047 & 0.455 & 0.077 & 0.208 & 0.666 & 0.014 & 1.528 & 0.05 \\
\hline 2009 & 0.157 & 0.756 & 0.646 & 0.556 & 0.783 & 0.351 & 0.102 & 0.142 & 0.181 & 1.049 & 0.851 & 0.012 \\
\hline 2010 & 0.102 & 0.624 & 0.875 & 1.810 & 1.082 & 0.070 & 1.418 & 0.233 & 0.231 & 0.018 & 0.821 & 0.012 \\
\hline 2011 & 2.525 & 0.625 & 0.010 & 2.213 & 1.657 & 0.147 & 0.432 & 0.210 & 0.002 & 0.618 & 0.512 & 0.061 \\
\hline 2012 & 1.080 & 0.651 & 0.041 & 2.713 & 1.561 & 0.081 & 1.421 & 0.221 & 0.019 & 0.671 & 0.523 & 0.052 \\
\hline 2013 & 1.270 & 0.625 & 0.050 & 1.741 & 1.721 & 0.231 & 0.721 & 0.119 & 0.061 & 0.051 & 0.031 & 0.042 \\
\hline 2014 & 0.737 & 0.637 & 0.146 & 2.846 & 1.231 & 0.074 & 1.221 & 0.302 & 0.141 & 0.472 & 0.64 & 0.271 \\
\hline $\mathrm{N}$ & 195 & & & 168 & & & 195 & & & 168 & & \\
\hline Intercept & 4.010 & 2.135 & 0.050 & -1.900 & 0.021 & 0.082 & -0.422 & 0.820 & 0.062 & -0.19 & 2.715 & 0.662 \\
\hline Countries & 17 & & & 17 & & & 17 & & & 17 & & \\
\hline Wald $\mathrm{X}^{2 c}$ & 1.254 & & 0.011 & 3.651 & & 0.041 & 3.143 & & 0.021 & 2.951 & & 0.013 \\
\hline Hansen & 34.300 & & 0.361 & 17.810 & & 0.376 & 11.420 & & 0.391 & 9.610 & & 0.380 \\
\hline $\operatorname{AR}(1)$ & 0.989 & & 0.003 & 0.721 & & 0.007 & 4.821 & & 0.041 & 0.861 & & 0.091 \\
\hline $\operatorname{AR}(2)$ & 0.731 & & 0.538 & 0.555 & & 0.612 & 0.751 & & 0.712 & 0.741 & & 0.915 \\
\hline $\mathrm{R}^{2}$ & 0.712 & & & 0.769 & & & 0.861 & & & 0.778 & & \\
\hline
\end{tabular}

Source: Own elaboration. 
Table 4

Sub-set regression models for efficiency-driven economies

\begin{tabular}{|c|c|c|c|c|c|c|c|c|c|c|c|c|}
\hline & \multicolumn{3}{|c|}{ Male SEA rate (Control) } & \multicolumn{3}{|c|}{ Male SEA rate (Actual Effects) } & \multicolumn{3}{|c|}{ Female SEA rate (Control) } & \multicolumn{3}{|c|}{ Female SEA rate (Actual Effects) } \\
\hline & $\begin{array}{l}\text { Beta } \\
\text { value }\end{array}$ & $\begin{array}{l}\text { Standard } \\
\text { error }\end{array}$ & $\begin{array}{l}\text { Significance } \\
\text { value }\end{array}$ & Beta value & $\begin{array}{l}\text { Standard } \\
\text { error }\end{array}$ & $\begin{array}{l}\text { Significance } \\
\text { value }\end{array}$ & Beta value & $\begin{array}{l}\text { Standard } \\
\text { error }\end{array}$ & $\begin{array}{l}\text { Significance } \\
\text { value }\end{array}$ & Beta value & $\begin{array}{l}\text { Standard } \\
\text { error }\end{array}$ & $\begin{array}{l}\text { Significance } \\
\text { value }\end{array}$ \\
\hline $\begin{array}{l}\text { Entrepreneurship rate } \\
1 \text {-year lag }\end{array}$ & 0.738 & 0.011 & 0.001 & 1.724 & 0.321 & 0.004 & 0.607 & 0.036 & 0.007 & 2.051 & 1.110 & 0.002 \\
\hline Population & 0.4326 & 1.3211 & 0.001 & 1.0831 & 1.7311 & 0.014 & 1.4732 & 1.2451 & 0.018 & -1.6321 & 6.8521 & 0.019 \\
\hline GDP & 0.009 & 0.007 & 0.041 & 0.003 & 0.001 & 0.156 & 0.007 & 0.008 & 0.051 & 0.006 & 0.005 & 0.097 \\
\hline GDP growth & 0.018 & 0.021 & 0.612 & 0.013 & 0.131 & 0.024 & 0.001 & 0.031 & 0.012 & -0.061 & 0.327 & 0.006 \\
\hline Access to finance & & & & 3.882 & 3.011 & 0.024 & & & & 4.554 & 0.434 & 0.006 \\
\hline $\begin{array}{l}\text { Entrepreneurial } \\
\text { education }\end{array}$ & & & & 2.641 & 4.141 & 0.623 & & & & 2.002 & 0.544 & 0.125 \\
\hline $\mathrm{R} \& \mathrm{D}$ transfer & & & & -1.665 & 4.364 & 0.932 & & & & 1.106 & 0.731 & 0.158 \\
\hline $\begin{array}{l}\text { Commercial } \\
\text { infrastructure access }\end{array}$ & & & & 0.203 & 6.031 & 0.671 & & & & 0.141 & 1.014 & 0.942 \\
\hline Physical infrastructure & & & & 2.112 & 1.117 & 0.003 & & & & 0.314 & 0.012 & 0.009 \\
\hline $\begin{array}{l}\text { Cultural, social norms } \\
\text { supportive }\end{array}$ & & & & -2.114 & 1.165 & 0.217 & & & & -6.119 & 0.446 & 0.312 \\
\hline 2005 & 2.431 & 1.143 & 0.103 & 2.203 & 1.041 & 0.614 & 0.431 & 0.235 & 0.023 & 1.714 & 1.161 & 0.023 \\
\hline 2006 & 2.439 & 1.567 & 0.256 & 2.451 & 1.311 & 0.508 & 0.111 & 0.211 & 0.014 & 1.651 & 1.121 & 0.008 \\
\hline 2007 & 0.417 & 0.840 & 0.004 & 0.110 & 2.221 & 0.917 & 0.121 & 0.161 & 0.078 & 1.071 & 1.211 & 0.019 \\
\hline 2008 & 1.385 & 0.513 & 0.061 & 1.017 & 2.036 & 0.082 & 0.065 & 0.107 & 0.129 & 0.025 & 1.417 & 0.026 \\
\hline 2009 & 0.349 & 0.645 & 0.012 & 0.445 & 0.651 & 0.689 & 0.103 & 0.031 & 0.176 & 1.058 & 0.741 & 0.001 \\
\hline 2010 & 0.013 & 0.513 & 0.024 & 1.701 & 1.432 & 0.019 & 1.317 & 0.122 & 0.154 & 0.027 & 0.711 & 0.034 \\
\hline 2011 & 2.414 & 0.514 & 0.007 & 2.102 & 1.546 & 0.078 & 0.321 & 0.129 & 0.289 & 0.507 & 0.401 & 0.058 \\
\hline 2012 & 1.190 & 0.541 & 0.009 & 2.602 & 1.432 & 0.053 & 1.311 & 0.119 & 0.728 & 0.561 & 0.412 & 0.039 \\
\hline 2013 & 1.380 & 0.514 & 0.041 & 1.630 & 1.611 & 0.069 & 0.611 & 0.228 & 0.329 & 0.041 & 0.021 & 0.124 \\
\hline 2014 & 0.626 & 0.526 & 0.058 & 2.735 & 1.221 & 0.084 & 1.119 & 0.201 & 0.196 & 0.361 & 0.531 & 0.319 \\
\hline $\mathrm{N}$ & 145 & & & 117 & & & 145 & & & 117 & & \\
\hline Intercept & 3.134 & 2.026 & 0.031 & -1.011 & 0.011 & 0.078 & -0.311 & 0.710 & 0.008 & -0.170 & 2.604 & 0.468 \\
\hline Countries & 16 & & & 16 & & & 16 & & & 16 & & \\
\hline Wald $X^{2 c}$ & 1.457 & & 0.001 & 4.568 & & 0.003 & 3.256 & & 0.004 & 2.354 & & 0.011 \\
\hline Hansen & 14.3 & & 0.258 & 16.17 & & 0.381 & 10.31 & & 0.379 & 7.520 & & 0.361 \\
\hline $\mathrm{AR}(1)$ & 0.731 & & 0.077 & 0.831 & & 0.041 & 0.759 & & 0.021 & 0.901 & & 0.018 \\
\hline $\operatorname{AR}(2)$ & 0.901 & & 0.211 & 0.771 & & 0.832 & 0.777 & & 0.921 & 0.891 & & 0.671 \\
\hline $\mathrm{R}^{2}$ & 0.729 & & & 0.841 & & & 0.711 & & & 0.731 & & \\
\hline
\end{tabular}

Source: Own elaboration. 
Table 5

Summary of results

\begin{tabular}{|c|c|c|c|c|c|c|}
\hline \multirow{2}{*}{ Hypothesis } & \multicolumn{2}{|c|}{ Complete Sample } & \multicolumn{2}{|c|}{ Efficiency-driven Sample } & \multicolumn{2}{|c|}{ Innovation-driven Sample } \\
\hline & Male SEA & Female SEA & Male SEA & Female SEA & Male SEA & Female SEA \\
\hline $\begin{array}{l}\text { H1a: Entrepreneurial education is directly associated with social } \\
\text { entrepreneurial activities. }\end{array}$ & Accepted & Accepted & Not Accepted & Not Accepted & Accepted & Accepted \\
\hline $\begin{array}{l}\text { H1b: The effect remains prominent mainly for men as compared } \\
\text { to women. }\end{array}$ & Accepted & Accepted & Not Accepted & Not Accepted & Accepted & Accepted \\
\hline $\begin{array}{l}\text { H2a: R\&D activities are positively associated with social } \\
\text { entrepreneurship at national level. }\end{array}$ & Not Accepted & Not Accepted & Not Accepted & Not Accepted & Not Accepted & Not Accepted \\
\hline $\begin{array}{l}\text { H2b: The effect remains prominent mainly for women as compared } \\
\text { to men. }\end{array}$ & Accepted & Accepted & Not Accepted & Not Accepted & Not Accepted & Not Accepted \\
\hline $\begin{array}{l}\text { H3a: Social entrepreneurship is positively associated with financial } \\
\text { support. }\end{array}$ & Accepted & Accepted & Accepted & Accepted & Accepted & Accepted \\
\hline $\begin{array}{l}\text { H3b: Financial support is more easily available for men than } \\
\text { women. }\end{array}$ & Accepted & Accepted & Not Accepted & Not Accepted & Not Accepted & Not Accepted \\
\hline $\begin{array}{l}\text { H4a: At the national level, social entrepreneurship is positively } \\
\text { associated with physical infrastructure. }\end{array}$ & Not Accepted & Accepted & Accepted & Accepted & Not Accepted & Not Accepted \\
\hline $\begin{array}{l}\text { H4b: Physical infrastructure is more accessible to men than } \\
\text { women. }\end{array}$ & Accepted & Accepted & Accepted & Accepted & Not Accepted & Not Accepted \\
\hline $\begin{array}{l}\text { H5a: Social entrepreneurship is positively associated with } \\
\text { commercial infrastructure. }\end{array}$ & Accepted & Accepted & Not Accepted & Not Accepted & Accepted & Accepted \\
\hline $\begin{array}{l}\text { H5b: Commercial infrastructure significantly influences the social } \\
\text { entrepreneurial actives of men and women. }\end{array}$ & Not Accepted & Accepted & Not Accepted & Not Accepted & Accepted & Accepted \\
\hline $\begin{array}{l}\text { H6a: Social and cultural norms are directly associated with social } \\
\text { entrepreneurial activities. }\end{array}$ & Accepted & Accepted & Not Accepted & Not Accepted & Not Accepted & Not Accepted \\
\hline $\begin{array}{l}\text { H6b: Social and cultural norms are more favorable for men than } \\
\text { women. }\end{array}$ & Accepted & Accepted & Not Accepted & Not Accepted & Not Accepted & Not Accepted \\
\hline
\end{tabular}

Source: Own elaboration.

\section{DISCUSSION AND CONCLUSION}

This study examines the influence of entrepreneurial ecosystem factors on the social entrepreneurial activities for both genders. We test our hypotheses using data from GEM 2015 by covering 35 countries for ten years (2004-2014). We also performed robustness checks by dividing our sample into two subsets; innovation and efficiency-driven economies. The results indicated that some factors of entrepreneurial ecosystem significantly influence social entrepreneurial activities. Our research confirms previous research findings that the entrepreneurial ecosystem plays a significant role in boosting social entrepreneurial activities (Doherty et al. 2018; Lounsbury et al. 2019). Findings reveal three entrepreneurial factors (access to finance, commercial infrastructure, and physical infrastructure) significantly influences SEA rates of both genders. Among selected six factors, our result supported $\mathrm{Hla}$ as we found a significant impact of entrepreneurial education on SEA and this result is in line with past studies (Jensen 2014; Mueller Brahm and Neck, 2015). H1b is not supported by the results and the reason would be that women are less likely to start an entrepreneurial venture without having appropriate education while men prefer learning from experience more than education (Kumar and Kalyani 2011; Schneider 2017).Further, this finding presents that the contemporary environment is promoting entrepreneurial education more for young women entrepreneurs over men entrepreneurs and eventually supporting social start-ups launched by women entrepreneurs. Thus, this finding suggests that entrepreneurial education can prepare young female entrepreneurs more effective for dealing with the practical challenges in the field of social entrepreneurship (Peterman and Kennedy 2003; Souitaris, Zerbinati and Al-Laham 2007).

Further, H2a is not supported by the results. While $\mathrm{H} 2 \mathrm{~b}$ is supported by the results of whole sample but not supported in the results of innovation and efficiency driven economies. The reason could be that as $\mathrm{R} \& \mathrm{D}$ transfer is inconsistent with the knowledge spill-over theory of entrepreneurship as it reveals that countries having cheap and fast R\&D activities have lower rates of SEA by depicting a negative and significant relationship between R\&D transfer and SEA rates for both genders. This result is in contrast to previous studies that claimed that $\mathrm{R} \& \mathrm{D}$ activities promote the transfer of knowledge and increases social entrepreneurial activates (Audretsch and Lehmann 2005; Acs et al. 2008). However, our result supports the outcomes of Markman et al. (2004) who found that R\&D incentive systems negatively influence entrepreneurial activities. Also, Morimoto (2018) found an inverted U-shaped linkage between R\&D and entrepreneurial rates. The reason behind this negative relationship may lie in the fact that individuals processes heterogeneous capabilities and R\&D subsidies reduces their intergenerational inequalities and thus reduces the number of entrepreneurs. As certainly, sponsorships promote $\mathrm{R} \& \mathrm{D}$ activities and encourage labor demand for the activities. This increase of labor demand, in turn, upsurges workers' income, creating it unattractive to be an entrepreneur. 
In this way subsidies of $\mathrm{R} \& \mathrm{D}$ promote $\mathrm{R} \& \mathrm{D}$ activities but also at the same time discourage entrepreneurs. Hence, our results suggest that sometimes a policy developed to promote research and development activities can have a negative influence on social entrepreneurial activities.

$\mathrm{H} 3 \mathrm{a}$ is supported by the results and $\mathrm{H} 3 \mathrm{~b}$ is only proved by whole sample results while not proved in innovation driven and efficiency driven economies. The findings suggest that having access to finance strongly enhances the spirit of social entrepreneurship among male and female entrepreneurs and this finding provides evidence to the previous research findings (Black and Satrahan 2002; Blanchflower et al. 2003). This outcome also finds its evidence in the results of innovation and efficiency-driven economies.

In case of H4a our results of complete sample proved that physical infrastructure supports women than men. While in efficiency driven sample $\mathrm{H} 4 \mathrm{a}$ is proved but in innovation driven sample it is not supported by the results. Overall, the results revealed that the physical infrastructure and services shared a positive and significant relationship with SEA rates of both genders and this finding provides evidence for the past studies that claimed the necessity of physical infrastructure for enhancing the social entrepreneurial activities (Amorós and Bosma 2014; Amorós et al. 2019). In case of H4b, as proposed its impact is found to be stronger for men than women in complete sample and efficiency driven sample results. The reason behind this result may lie in the fact that the physical infrastructure such as operating space, communication facilities and transportation is more assessable to men as compared to women. Because women prefer to work from home thus assessing physical infrastructure shares a stronger relationship with men as compared to women (Bitzenis and Nito 2005).

In view of results $\mathrm{H} 5 \mathrm{a}$ is found to be accepted for complete and innovation driven sample. While, H5b finds partial support from results as the commercial infrastructure reflected a positive and significant relationship with social entrepreneurial activities in the case of only female respondents of complete sample. Surprisingly commercial infrastructure showed an insignificant relationship with SEA rates in the case of male respondents, maybe since the current feminist economic arguments are enhancing the awareness regarding the importance of women entrepreneurs and commercial infrastructure becomes more favorable for women than men in establishing new social start-ups (Karadeniz and Ozdemir 2009). Further, the influence of commercial infrastructure on SEA rates for both males and females is also found to be positively and significantly related to the results of innovation-driven economies.

In the perspective of cultural and social norms, the results of $\mathrm{H} 6 \mathrm{a}$ and $\mathrm{H} 6 \mathrm{~b}$ indicated a positive and significant relationship between culture and SEA rates for both genders and culture seems to be more favorable for social entrepreneurial activities of men. This result also finds support from the past studies (Hofstede 1980; Khursheed et al., 2018; Khursheed et al. 2019).

Regarding social entrepreneurship theory, we found that global entrepreneurial factors have a considerable impact on prevalence rates of social business ventures and the goal of starting a social business venture is not independent of the entrepreneurial ecosystem and its factors.
This study made an effort to explore how different aspects of an entrepreneurial ecosystem influences social entrepreneurial activities for both men and women at the national level. We found that considerably three factors of an entrepreneurial ecosystem influence social entrepreneurship rates for men and women. This study provides valuable information for policymakers about the factors that drive social entrepreneurial activities. Further, the finding provides researchers and social entrepreneurs a deeper insight regarding the key factors leading to social business venture success. Further, the model analyzed in this study provides the key context to comprehend the relationship between social entrepreneurship and its factors. The results may also facilitate the researchers and academicians to explore new ways for understanding social entrepreneurship from the perspective of entrepreneurial ecosystem.

\section{IMPLICATIONS AND FUTURE DIRECTIONS}

The implications of this study are both theoretical and practical. From the theoretical perspective, its contribution is to improve the existing studies on SE by introducing a framework based on entrepreneurial factors to explore the un-examined areas. This study is capable to fill the gap in the literature by analyzing the relationship between entrepreneurial factors and SE in various countries by drawing on empirical data from Global Entrepreneurship Monitor (GEM). Hence, the findings of this study facilitate scholars and analysts with the latest empirical advancements in the field of SE, specifically by considering 35 different countries in this regard. Furthermore, this study enlightens the major differences between commercial entrepreneurship and social entrepreneurship. From a practical perspective, this study reveals that entrepreneurial factors are recognized as the significant drivers of SE. Particularly, this study gives future directions to academicians that how culture, gender and entrepreneurial factors can be examined to improve the effectiveness of an organizations' practices and behavior, especially those who work for the uplift of society. The study provides practical implications for future social entrepreneurs particularly in innovation and efficiency driven economies. Further, the study expands future research avenues on social entrepreneurship in diverse contexts. The findings highlights that social entrepreneurship is the key source for social value creation in an economy. Thus, by focusing on the key constructs analyzed in this study social entrepreneurial activities of men and women can be boosted.

This study provides two limitations. First, the GEM database contains data from 75 countries for entrepreneurial intentions. While data on SEA and all six entrepreneurial factors were accessible only for 35 countries. After merging data from three databases depicted that 35 countries have attained values common in GEM SEA, NES and APS. Owing to constraints in the availability of GEM data, the second limitation is the data range covering the period of ten years (2005-2014) in this study.

Despite these limitations, this study recommends new trends for academicians and researchers. As discussed earlier in the literature, SE has been generally investigated with the help of two components (Austin, Stevenson and Wei-Skillern 2006; Dacin et al. 2010), which means that by concentrating on the relative 
balance between self-satisfaction and other's interests in the formation of an entrepreneurial process. Therefore, future research is required to investigate the influence of entrepreneurial factors on both components of SE as well as on the relative balance. Questions that may contribute invaluable research include:

- What combination of entrepreneurial factors is required to sustain the pace and growth of social entrepreneurial activities?

- How do different entrepreneurial factors affect social and entrepreneurial orientation?

- How culture and gender mediate the relationship between entrepreneurial factors and the social venture creation process?

The development of these research questions highlights the presence of a still undiscovered field of examination, within which academicians may take benefit of these outcomes. Particularly, social identity theory, resource dependency theory and institutional theory may be utilized to join gendered based approaches in social entrepreneurship study.

\section{REFERENCES}

Acs, Z., Audretsch, D., 2006. Handbook of entrepreneurship research: An interdisciplinary survey and introduction (Vol. 1). Springer Science \& Business Media.

Acs, Z. J., Audretsch, D. B. and Lehmann, E. E., 2013. The knowledge spillover theory of entrepreneurship. Small Business Economics, 41(4), 757-774.

Acs, Z. J., Braunerhjelm, P., Audretsch, D. B. and Carlsson, B., 2009. The knowledge spillover theory of entrepreneurship. Small Business Economics, 32(1), 15-30.

Acs, Z. J., Desai, S. and Hessels, J., 2008. Entrepreneurship, economic development and institutions. Small Business Economics, 31(3), 219234.

Acs, Z. J., Stam, E., Audretsch, D. B. and O'Connor, A., 2017. The lineages of the entrepreneurial ecosystem approach. Small Business Economics, 49(1), 1-10.

Ahl, H. 2004. The scientific reproduction of gender inequality: A discourse analysis of research texts on women's entrepreneurship. Liber.

Ahmed, I., Nawaz, M.M., Ahmad, Z., Shaukat, M.Z., Usman, A., Rehman, W., U. and Ahmed, N., 2010. Determinants of students'entrepreneurial career intentions: evidence from businessgraduates. European Journal of Social Sciences, 15(2), 14-22

Alibhai, S., Donald, A. A., Goldstein, M., Oguz, A. A., Pankov, A. and Strobbe, F., 2019. Gender Bias in SME Lending: Experimental Evidence from Turkey. World Bank Policy Research Working Paper, (9100).

Alter, K., 2007. Social enterprise typology. Virtue Ventures LLC, 12, $1-124$.

Alvord, S. H., Brown, L. D. and Letts, C. W., 2004. Social entrepreneurship and societal transformation: An exploratory study. The Journal of Applied Behavioral Science, 40(3), 260-282.

Amorós, J. E. and Bosma, N., 2014. Global Entrepreneurship Monitor 2013 global report. Global Entrepreneurship Monitor. Retrieved from https://www.gemconsortium.org/report/gem-2013-global-report.

Amorós, J. E., Poblete, C. and Mandakovic, V., 2019. R\&D transfer, policy and innovative ambitious entrepreneurship: evidence from Latin American countries. The Journal of Technology Transfer, 44, 1396-1415.

Arellano, M., 2003. Panel data econometrics. Oxford: Oxford University Press.
Arellano, M. and Bond, S., 1991. Some tests of specification for panel data: Monte Carlo evidence and an application to employment equations. The Review of Economic Studies, 58(2), 277-297.

Ashrafi, D. M., Sarker, M. A. R., Binti Hashim, J., Haque, A., and Nayan, F. K., 2020. An exploration of the youths perception toward social entrepreneurship development: Evidence from Bangladesh. JEMA: Jurnal Ilmiah Bidang Akuntansi Dan Manajemen, 17(1), 88-104. https://doi.org/10.31106/jema.v17i1.5539

Audretsch, D. B. and Lehmann, E. E., 2005. Does the knowledge spillover theory of entrepreneurship hold for regions? Research Policy, 34(8), 1191-1202.

Audretsch, D. B., Heger, D. and Veith, T., 2015. Infrastructure and entrepreneurship. Small Business Economics, 44(2), 219-230.

Austin, J., Stevenson, H. and Wei-Skillern, J., 2006. Social and commercial entrepreneurship: same, different, or both? Entrepreneurship Theory and Practice, 30(1), 1-22.

Beckmann, M., Zeyen, A. and Krzeminska, A., 2014. Mission, finance, and innovation: The similarities and differences between social entrepreneurship and social business. In Social business. Berlin, Heidelberg: Springer, 23-41.

Bhushan, B., 2020. Motivational Model of Social Entrepreneurship: Exploring the Shaping of Engagement of Social Entrepreneur. In Methodological Issues in Social Entrepreneurship Knowledge and Practice. Singapore: Springer, 111-136.

Bosma, N., Schutjens, V. and Volker, B., 2016. Local social entrepreneurship and social capital. In Handbook of Social Capital and Regional Development. Edward Elgar Publishing, 55-81.

Bitzenis, A. and Nito, E., 2005. Obstacles to entrepreneurship in a transition business environment: the case of Albania. Journal of Small Business and Enterprise Development, 12(4), 564-578.

Black, S. E. and Strahan, P. E., 2002. Entrepreneurship and bank credit availability. The Journal of Finance, 57(6), 2807-2833.

Blanchflower, D. G., Levine, P. B. and Zimmerman, D. J., 2003. Discrimination in the small-business credit market. Review of Economics and Statistics, 85(4), 930-943.

Brush, C., Edelman, L. F., Manolova, T. and Welter, F., 2019. A gendered look at entrepreneurship ecosystems. Small Business Economics, 53(2), 393-408.

Canestrino, R., Ćwiklicki, M., Magliocca, P. and Pawełek, B., 2020. Understanding social entrepreneurship: A cultural perspective in business research. Journal of Business Research, 110, 132-143.

Capella-Peris, C., Gil-Gómez, J., Martí-Puig, M. and Ruíz-Bernardo, P., 2020. Development and validation of a scale to assess social entrepreneurship competency in higher education. Journal of Social Entrepreneurship, 11(1), 23-39.

Cohen, B. and Winn, M. I., 2007. Market imperfections, opportunity and sustainable entrepreneurship. Journal of Business Venturing, 22(1), 29-49.

Cater, J. J. and Beal, B. D., 2015. Servant leadership in multigenerational family firms. Journal of Applied Management and Entrepreneurship, 20(4), 25.

Chandra, Y. and Paras, A., 2020. Social entrepreneurship in the context of disaster recovery: Organizing for public value creation. Public Management Review, 1-22.

Craney, T. A. and Surles, J. G., 2002. Model-dependent variance inflation factor cut off values. Quality Engineering, 14(3), 391-403.

Clark, K. D., Newbert, S. L. and Quigley, N. R., 2018. The motivational drivers underlying for-profit venture creation: Comparing social and commercial entrepreneurs. International Small Business Journal, 36(2), 220-241.

Dacin, P. A., Dacin, M. T. and Matear, M., 2010. Social entrepreneurship: Why we don't need a new theory and how we move forward from here. Academy of Management Perspectives, 24(3), 37-57. 
Davis, K., 1973. The case for and against business assumption of social responsibilities. Academy of Management Journal, 16, 312-322.

Dawson, P. and Daniel, L., 2010. Understanding social innovation: a provisional framework. International Journal of Technology Management, 51(1), 9-21.

De Bruin, A. M. and Ferrante, F. M., 2011. Bounded opportunity: A knowledge-based approach to opportunity recognition and development. Entrepreneurship Research Journal, 1(4).

Deb, R., and Bhatt, D. K., 2020. Technology integration through digital learning hub in skill-oriented entrepreneurial education. Journal of Engineering Education Transformations, 33, 503-509.

Dees, J. G. and Elias, J., 1998. The challenges of combining social and commercial enterprise. Business Ethics Quarterly, 8(1), 165-178.

Delmar, F. and Davidsson, P., 2000. Where do they come from? Prevalence and characteristics of nascent entrepreneurs. Entrepreneurship \& Regional Development, 12(1), 1-23.

Desa, G., 2012. Resource mobilization in international social entrepreneurship: Bricolage as a mechanism of institutional transformation. Entrepreneurship Theory and Practice, 36(4), 727-751.

DeTienne, D. R. and Chandler, G. N., 2004. Opportunity identification and its role in the entrepreneurial classroom: A pedagogical approach and empirical test. Academy of Management Learning \& Education, 3(3), 242-257.

Digan, S. P., Sahi, G. K., Mantok, S. and Patel, P. C., 2019. Women's Perceived Empowerment in Entrepreneurial Efforts: The Role of Bricolage and Psychological Capital. Journal of Small Business Management, 57(1), 206-229.

Dwivedi, A. and Weerawardena, J., 2018. Conceptualizing and operationalizing the social entrepreneurship construct. Journal of Business Research, 86, 32-40.

Doherty, B., 2018. Research in the social enterprise journal-from the margins to the mainstream. Social Enterprise Journal, 14(1), 108-116.

Etzioni, A., 1987. Entrepreneurship, adaptation and legitimation: a macro-behavioral perspective. Journal of Economic Behavior \& Organization, 8(2), 175-189.

Feld, B., 2012. Startup communities: Building an entrepreneurial ecosystem in your city. John Wiley \& Sons.

Ferreira, J. J., Fernandes, C. I., Peres-Ortiz, M. and Alves, H., 2017. Conceptualizing social entrepreneurship: perspectives from the literature. International Review on Public and Nonprofit Marketing, 14(1), 73-93.

Friedman, M., 1970. The social responsibility of business is to increase its profits. The New York Times Magazine.

Ghani, E., Kerr, W. R. and O'connell, S., 2014. Spatial determinants of entrepreneurship in India. Regional Studies, 48(6), 1071-1089.

Gottleib, E. and Ross, J. A., 1997. Made not born: HBS courses and entrepreneurial management. Harvard Business School Bulletin, 73(2), 41-45.

Goyal, M. and Parkash, J., 2011. Women entrepreneurship in India-problems and prospects. International Journal of Multidisciplinary Research, 1(5), 195-207.

Halberstadt, J., Timm, J. M., Kraus, S. and Gundolf, K., 2019. Skills and knowledge management in higher education: how service learning can contribute to social entrepreneurial competence development. Journal of Knowledge Management, 23(10), 1925-1948.

Hall, J. K., Daneke, G. A. and Lenox, M. J., 2010. Sustainable development and entrepreneurship: Past contributions and future directions. Journal of Business Venturing, 25(5), 439-448.

Harrington, C. and Clarkson, G. S., 2019. Native American Approaches to Social Entrepreneurship. In Mission-Driven Approaches in Modern Business Education. IGI Global, 46-61.

Hashmi, S., 2019. Entrepreneurship: Challenges or opportunities for women. International Journal of Research in Social Sciences, 9(5), 366-374.
Hofstede, G., 1980. Motivation, leadership, and organization: do American theories apply abroad? Organizational Dynamics, 9(1), 42-63.

Honig, B., 2004. Entrepreneurship education: Toward a model of contingency-based business planning. Academy of Management Learning \& Education, 3(3), 258-273.

Hsu, C. Y. and Wang, S. M., 2019. Social entrepreneurial intentions and its influential factors: A comparison of students in Taiwan and Hong Kong. Innovations in Education and Teaching International, 56(3), 385-395.

House, R. J., 1998. A brief history of GLOBE. Journal of Managerial Psychology, 13(3/4), 230-240.

Inglehart, R., 1997. Modernization and post modernization: Cultural, economic, and political change in 43 societies. Princeton university press.

Jensen, T. L., 2014. A holistic person perspective in measuring entrepreneurship education impact-Social entrepreneurship education at the Humanities. The International Journal of Management Education, 12(3), 349-364.

Kedmenec, I. and Strašek, S., 2017. Are some cultures more favourable for social entrepreneurship than others? Economic research-Ekonomska istraživanja, 30(1), 1461-1476.

Karadeniz, E. and Ozdemir, O., 2009. Entrepreneurship in Turkey and developing countries: A comparison of activities, characteristics, motivation and environment for entrepreneurship. Mibes Transactions, 3(1), 30-45.

Khursheed, A., Mustafa, F., Fatima, M. and Khalid, F., 2019. Antecedents of Entrepreneurial Intentions: A Cross-Country Study of Northern Europe and the Danube Region. Iranian Journal of Management Studies, 12(4), 593-627.

Khursheed, A., Mustafa, F., Fatima, M. and Siddique, F., 2018. Entrepreneurial Intentions: GEM based empirical analysis on the northern Europe and Asian countries. International Journal of Entrepreneurial Knowledge, 6(2), 59-70.

Kong, E., 2019. Harnessing and advancing knowledge in social enterprises: Theoretical and operational challenges in the refugee settlement experience. Journal of Social Entrepreneurship, 10(2), 193-210.

Korsgaard, S., 2011. Opportunity formation in social entrepreneurship. Journal of Enterprising Communities: People and Places in the Global Economy, 5(4), 265-285.

Kruse, P., Wach, D., Costa, S. and Moriano, J. A., 2019. Values Matter, Don't They?-Combining Theory of Planned Behavior and Personal Values as Predictors of Social Entrepreneurial Intention. Journal of Social Entrepreneurship, 10(1), 55-83.

Kumar, D. and Kalyani, B., 2011. Motivational factors, entrepreneurship and education: Study with reference to women in SMEs. Far East Journal of Psychology and Business, 3(2), 14-35.

Lehner, O. M. and Kansikas, J., 2012. Opportunity recognition in social entrepreneurship: A thematic meta-analysis. The Journal of Entrepreneurship, 21(1), 25-58.

Levie, J. and Autio, E., 2008. A theoretical grounding and test of the GEM model. Small Business Economics, 31(3), 235-263.

Lounsbury, M., Cornelissen, J., Granqvist, N. and Grodal, S., 2019. Culture, Innovation and Entrepreneurship. Innovation, 21(1), 1-12.

Lumpkin, G.T., Moss, T.W., Gras, D.M., Kato, S. and Amezcua, A.S., 2013. Entrepreneurial processes in social contexts: how are they different, if at all? Small Business Economics, 40, 761-783.

Mair, J. and Marti, I., 2006. Social entrepreneurship research: A source of explanation, prediction, and delight. Journal of World Business, 41(1), 36-44.

Markman, G. D., Gianiodis, P. T., Phan, P. H. and Balkin, D. B., 2004. Entrepreneurship from the ivory tower: do incentive systems matter? The Journal of Technology Transfer, 29(3-4), 353-364.

Marlow, S. and Patton, D., 2005. All credit to men? Entrepreneurship, finance, and gender. Entrepreneurship Theory and Practice, 29(6), 717-735. 
Mittal, M. and Vyas, R. K., 2011. A study of psychological reasons for gender differences in preferences for risk and investment decision making. IUP Journal of Behavioral Finance, 8(3).

Morimoto, T., 2018. Occupational choice and entrepreneurship: effects of R\&D subsidies on economic growth. Journal of Economics, 123(2), 161-185.

Mueller, S., Brahm, T. and Neck, H., 2015. Service learning in social entrepreneurship education: Why students want to become social entrepreneurs and how to address their motives. Journal of Enterprising Culture, 23(03), 357-380.

Mustafa, F. Khursheed, A. and Fatima, M., 2018. Impact of global financial crisis on financially innovative microfinance institutions in South Asia. Financial Innovation, 4(1), 1-11.

Omorede, A., 2014. Exploration of motivational drivers towards social entrepreneurship. Social Enterprise Journal, 10(3), 239-267.

Pergelova, A., Manolova, T., Simeonova-Ganeva, R. and Yordanova, D., 2019. Democratizing Entrepreneurship? Digital Technologies and the Internationalization of Female-Led SMEs. Journal of Small Business Management, 57(1), 14-39.

Perrini, F., Vurro, C. and Costanzo, L. A., 2010. A process-based view of social entrepreneurship: From opportunity identification to scaling-up social change in the case of San Patrignano. Entrepreneurship and Regional Development, 22(6), 515-534.

Peterman, N. E. and Kennedy, J., 2003. Enterprise education: Influencing students' perceptions of entrepreneurship. Entrepreneurship Theory and Practice, 28(2), 129-144.

Prieto, L. C., Phipps, S. T. and Friedrich, T. L., 2012. Social entrepreneur development: An integration of critical pedagogy, the theory of planned behavior and the ACS model. Academy of Entrepreneurship Journal, 18(2).

Reynolds, P., Bosma, N., Autio, E., Hunt, S., De Bono, N., Servais, I. and Chin, N., 2005. Global entrepreneurship monitor: Data collection design and implementation 1998-2003. Small Business Economics, 24(3), 205-231.

Ruvio, A. A. and Shoham, A., 2011. A multilevel study of nascent social ventures. International Small Business Journal, 29(5), 562-579.

Rey-Martí, A., Ribeiro-Soriano, D. and Palacios-Marqués, D., 2016. A bibliometric analysis of social entrepreneurship. Journal of Business Research, 69(5), 1651-1655.

Sahasranamam, S. and Nandakumar, M. K., 2020. Individual capital and social entrepreneurship: Role of formal institutions. Journal of Business Research, 107, 104-117.

Santos, F. M., 2012. A positive theory of social entrepreneurship. Journal of Business Ethics, 111(3), 335-351.

Schwartz, S. H., 1994. Are there universal aspects in the structure and contents of human values? Journal of Social Issues, 50(4), 19-45.
Seelos, C. and Mair, J., 2007. Profitable business models and market creation in the context of deep poverty: A strategic view. Academy of Management Perspectives, 21(4), 49-63.

Servantie, V. and Rispal, M. H., 2018. Bricolage, effectuation, and causation shifts over time in the context of social entrepreneurship. Entrepreneurship \& Regional Development, 30(3-4), 310-335.

Shane, S. A., 1996. Hybrid organizational arrangements and their implications for firm growth and survival: A study of new franchisors. Academy of Management Journal, 39(1), 216-234.

Sharir, M. and Lerner, M., 2006. Gauging the success of social ventures initiated by individual social entrepreneurs. Journal of World Business, 41(1), 6-20.

Shaw, E. and Carter, S., 2007. Social entrepreneurship: Theoretical antecedents and empirical analysis of entrepreneurial processes and outcomes. Journal of Small Business and Enterprise Development, 14(3), 418-434.

Schneider, K., 2017. Promoting the entrepreneurial success of women entrepreneurs through education and training. Science Journal of Education, 5(2), 50-59.

Souitaris, V., Zerbinati, S. and Al-Laham, A., 2007. Do entrepreneurship programmes raise entrepreneurial intention of science and engineering students? The effect of learning, inspiration and resources. Journal of Business Venturing, 22(4), 566-591.

Short, J. C., Moss, T. W. and Lumpkin, G. T., 2009. Research in social entrepreneurship: Past contributions and future opportunities. Strategic Entrepreneurship Journal, 3(2), 161-194.

Thompson, J. L., 2002. The world of the social entrepreneur. The International Journal of Public Sector Management, 15, 412-431.

Urban, B. and Kujinga, L., 2017. The institutional environment and social entrepreneurship intentions. International Journal of Entrepreneurial Behavior \& Research, 23(4), 638-655.

Van Slyke, D. M. and Newman, H. K., 2006. Venture philanthropy and social entrepreneurship in community redevelopment. Nonprofit Management and Leadership, 16(3), 345-368.

Van Stel, A., Storey, D. J. and Thurik, A. R., 2007. The effect of business regulations on nascent and young business entrepreneurship. Small Business Economics, 28(2-3), 171-186.

Wakkee, I., van der Sijde, P., Vaupell, C. and Ghuman, K., 2019. The university's role in sustainable development: Activating entrepreneurial scholars as agents of change. Technological Forecasting and Social Change, 141, 195-205.

Welter, F., 2011. Contextualizing entrepreneurship-conceptual challenges and ways forward. Entrepreneurship Theory and Practice, 35(1), 165-184.

Zahra, S. A., Gedajlovic, E., Neubaum, D. O. and Shulman, J. M., 2009. A typology of social entrepreneurs: Motives, search processes and ethical challenges. Journal of Business Venturing, 24(5), 519-532. 